\title{
RESERVOIR EFFECT OF COASTAL WATERS OFF WESTERN AND NORTHWESTERN GALICIA
}

\author{
António M Monge Soares \\ Dep. de Química, Instituto Tecnológico e Nuclear, Estrada Nacional 10, 2685-953 Sacavém, Portugal. Corresponding author. \\ Email: amsoares@itn.pt.
}

João M Alveirinho Dias

Faculdade de Ciências do Mar e do Ambiente, Universidade do Algarve, Campus de Gambelas, 8000-117 Faro, Portugal. Email: jdias@ualg.pt.

\begin{abstract}
Differences in the radiocarbon ages of closely associated marine mollusk shells and terrestrial material (charred wood or bones) from several Galician archaeological contexts are significant from the Iron Age to Medieval times. $\Delta R$ values show high variability, ranging from $-280 \pm 70$ to $270 \pm 40{ }^{14} \mathrm{C}$ yr. The set of $\Delta R$ values also presents a strong positive peak $\left(\Delta R=270 \pm 40{ }^{14} \mathrm{C}\right.$ yr $)$ at $860 \pm 90 \mathrm{BP}$, which matches another peak found for western Portuguese coastal waters. The data obtained, namely the negative or close to zero $\Delta \mathrm{R}$ values, suggest that the reduced offset between atmospheric and surface water ${ }^{14} \mathrm{C}$ content is due to the existence of a strong stratification of the water column and environmental factors in the Galician rías during the Iron Age and the Medieval period.
\end{abstract}

\section{INTRODUCTION}

The western coast of the Iberian Peninsula $\left(37-43^{\circ} \mathrm{N}\right)$ is the northern boundary of the NW Africa coastal upwelling system. At these latitudes, shelf winds follow a seasonal pattern connected with the large-scale climatology of the Northeastern Atlantic Ocean (Wooster et al. 1976). The western Iberian shelf forms a complex oceanographic system due to its location, size, coastline, and bathymetric features, where a variety of micro-, meso-, and macro-scale physical processes occur, including coastal upwelling and coastal downwelling. The dominant wind pattern in this coast is a consequence of the location of the Azores high, which causes changes in wind direction and intensity. These changes, consequently, modify the hydrographic structure of the water column. Northerly winds predominate from April to September, causing upwelling; favorable downwelling occurs from October to March when the coast is under the influence of southerly winds due to the reinforcement of the Iceland low, while the Azores high occupies its most southern position (Fiúza 1982, 1983; Fiúza et al. 1982; Ferreira 1984; Nogueira et al. 2003; Lorenzo et al. 2005; Varela et al. 2005).

Galicia is located at the northern limit of the upwelling area of the NE Atlantic. Cape Finisterre is the most northwesterly point in the Galician region and at this distinctive topographic feature, the western coastline abruptly changes its near south-north orientation to a southwest-northeast direction (see Figure 1). The western Galician coast extends from about $42-43^{\circ} \mathrm{N}$ and is characterized by a fairly regular topography and a coastline with 4 main embayments or rías. The Rías of Galicia are flooded tectonic valleys and penetrate the coast with their axes almost perpendicular to the coastline. The rías to the south of Cape Finisterre are called the Rías Baixas (from north to south: Muros-Noia, Arousa, Pontevedra, and Vigo), while those to the north of the Cape are known as the Rías Altas. Among these, the rías of La Coruña, Betanzos, and Ferrol are the most important (Prego et al. 1999). Most rivers on the Galician coast do not flow directly into the sea but enter via the inner segment of the rías. Freshwater input follows a seasonal pattern with lower flow in summer. Moreover, the annual river input is low and similar for both groups of rías; summer processes, particularly coastal upwelling, exert a far greater influence in the rías hydrography than the river discharge (Prego et al. 1999). 


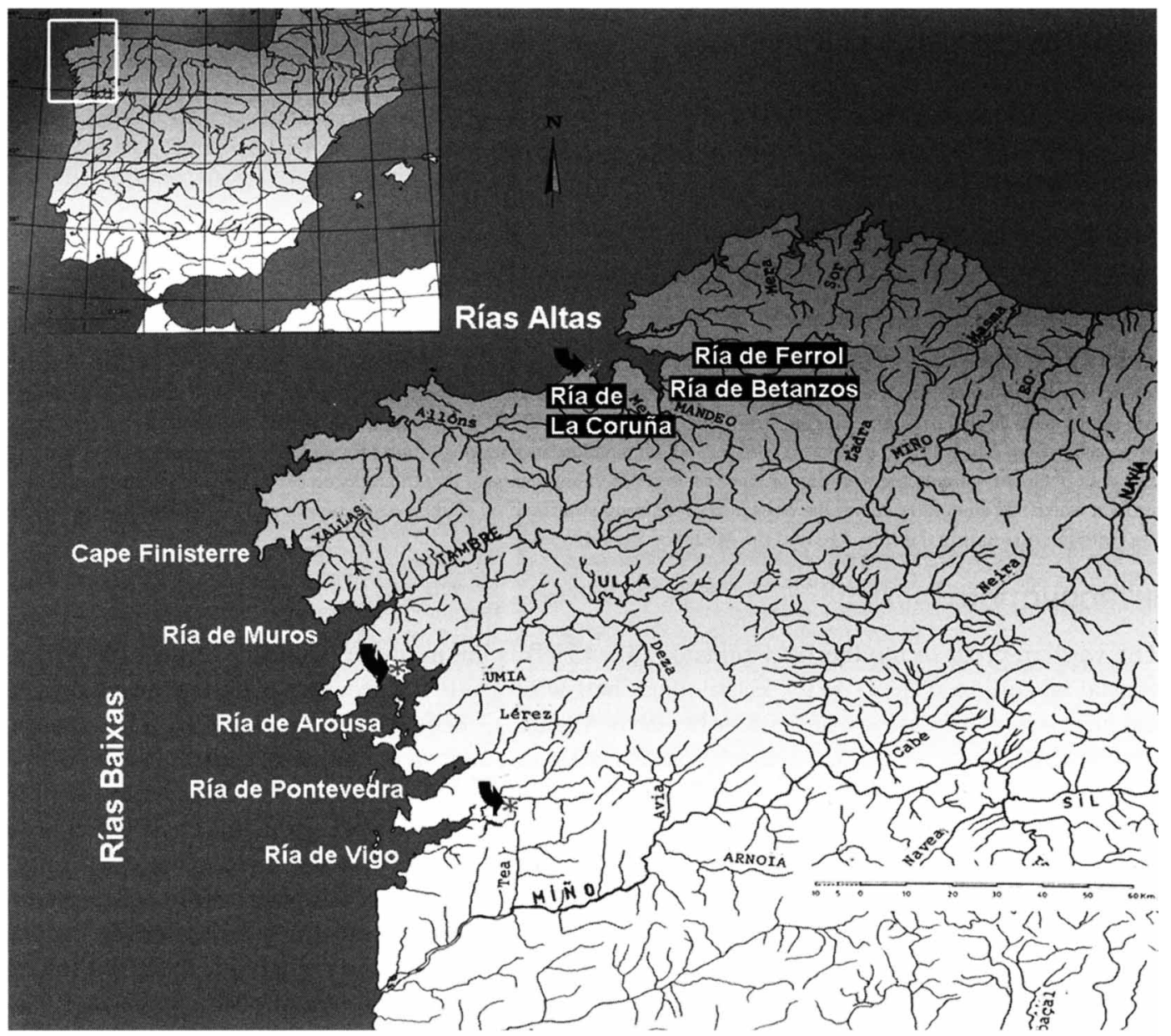

Figure 1 Galician rías and locations of the sampled archaeological sites

The wind field in the Cape Finisterre area has high spatial and temporal variability throughout the year. Nevertheless, an outstanding feature of the Galician coast is the persistent upwelling near Cape Finisterre (Torres et al. 2003). This recurrent upwelling center off Cape Finisterre divides the study area into 2 regions, which differ not only in the occurrence and intensity of winds, but also in the origin of the upwelled water. Eastern North Atlantic Central Water of subpolar origin $\left(\mathrm{ENACW}_{\mathrm{sp}}\right)$ has been recorded as upwelled water north of Cape Finisterre when northeastern winds predominate. South of the Cape, ENACW $\mathrm{sp}_{\mathrm{sp}}$ has been observed during the spring upwelling, whereas ENACW of subtropical origin $\left(\mathrm{ENACW}_{\mathrm{st}}\right)$ prevailed during the summer upwelling (Castro et al. 2000).

The water circulation in the Rías Baixas is 2-layered. The bottom layer corresponds to upwelled East North Atlantic Central Water (ENACW) that enters the ría during an upwelling event and pushes the surface layer water out of the ría (Borges and Frankignoulle 2002). The outwelled surface water is modified ENACW that entered the ría during the upwelling event of the previous upwelling cycle (with a period typically of 14 days, following Álvarez-Salgado et al. 1993). Thus, during the upwelling season $60 \%$ of shelf surface waters off the Rías Baixas consist of fresh ENACW upwelled in situ. The remaining $40 \%$ consists of upwelled ENACW that previously entered the rías and is sub- 
sequently outwelled after thermohaline modification. During the downwelling season, $40 \%$ of warm and salty oceanic subtropical surface water, which is piled on the shelf by the predominant southerly winds, enters the rías (Álvarez-Salgado et al. 2000). Consequently, water circulation patterns in the outer and middle segments of the Rías Baixas are controlled by shelf wind-stress, so these rías behave as extensions of the shelf rather than as proper estuaries. Only the innermost part of the rías may strictly be considered as an estuary. The hydrographic system of the Rías Altas is different from that of the Rías Baixas. Besides a lesser intensity of upwelling in the corresponding shelf, the existence of a thermohaline front near the coastline impedes to a great extent the penetration of upwelled water into these rías (Prego and Bao 1997; Prego et al. 1999).

As upwelled waters are depleted in radiocarbon relative to sea surface water, the ${ }^{14} \mathrm{C}$ content of marine shells inhabiting coastal regions can be used as an upwelling proxy. Stuiver et al. (1986) modeled the response of the world oceans to atmospheric ${ }^{14} \mathrm{C}$ variations. From this modeling, $2 \mathrm{cal}-$ ibration curves for marine samples have been derived: one related to the deep ocean and the other to the sea surface water (mixed layer). Regional differences in ${ }^{14} \mathrm{C}$ content between the surface water of a specific region and the average surface water are due to several causes and anomalies, particularly the upwelling of deep water. Thus, a parameter, denoted as $\Delta \mathrm{R}$, can be defined as the difference between the reservoir age of the mixed layer of the regional ocean and the reservoir age of the mixed layer of the average world ocean. $\Delta \mathrm{R}$ values are often determined for a particular geographical region by ${ }^{14} \mathrm{C}$ dating of marine mollusk shells of historic (known) age, collected alive before 1950, i.e. of pre-bomb age (Stuiver et al. 1986). Another approach to quantification of $\Delta R$ is dating pairs of samples of the same age but of different origin (terrestrial and marine) and converting the terrestrial biosphere sample ${ }^{14} \mathrm{C}$ age into a marine model age; this marine model age is then deducted from the ${ }^{14} \mathrm{C}$ age of the associated marine sample to yield $\Delta R$ (Stuiver and Braziunas 1993). Although reservoir ages, $R(t)$ - defined as the difference between conventional ${ }^{14} \mathrm{C}$ dates from a pair of coeval samples that lived in different carbon reservoirs (Stuiver et al 1986) - are time-dependent, $\Delta \mathrm{R}$ is not unless some change of oceanographic conditions restricted to the considered regional ocean has occurred. Since rates of regional upwelling can vary in the course of time and the intensity of the ${ }^{14} \mathrm{C}$ depletion in the mixed layer depends upon the wind-driven coastal upwelling, it is likely that values of $\Delta \mathrm{R}$ can also vary in the course of time (Stuiver and Braziunas 1993:155; Kennett et al. 1997; Ingram 1998; Ascough et al. 2004; Soares and Dias 2006). A $\Delta R$ value higher than the modern value (i.e. the one determined using marine mollusk shells of historic known age) will probably represent a period of higher than modern upwelling rates and, conversely, periods of lower than modern $\Delta R$ value may represent periods of weaker coastal upwelling. So, as a measure of the regional enhancement or depletion of radiocarbon, $\Delta \mathrm{R}$ can also be used as an upwelling proxy, which provides the most direct signal of upwelling activity (Diffenbaugh et al. 2003).

From previous studies concerning the coastal upwelling off Portugal, a mean value for $\Delta \mathrm{R}(280 \pm 35$ ${ }^{14} \mathrm{C} \mathrm{yr}$ ) was calculated using shells from marine mollusks collected alive along the western Portuguese coast between 1886 and 1937 (Soares 1989; Soares and Cabral 1993). This value is in accordance with the occurrence of an active upwelling of strong intensity as exists today. In compliance with the definition, $\Delta \mathrm{R}$ was supposed to be constant (Stuiver et al. 1986). Nevertheless, the research carried out later shows that differences in the ${ }^{14} \mathrm{C}$ ages of closely associated marine mollusk shells and terrestrial material (charcoal or bones) from several Portuguese archaeological contexts are significant through the Holocene. $\Delta \mathrm{R}$ values range from $940 \pm 50$ to $-160 \pm 40{ }^{14} \mathrm{C}$ yr (Soares and Dias 2006). Some primary observations based on these data can be made: i) during the Holocene important changes have occurred in the ocean reservoir effect off the Portuguese coast; ii) these fluctuations may be correlated with regional oceanographic changes, namely with changes in the strength 
of coastal upwelling; and iii) these changes suggest some sort of variability of the climatic factors forcing coastal upwelling off Portugal (Soares 1993; Soares and Dias 2006).

Since the upwelling area of the Galician coast can be considered as the northern limit of the western Iberian upwelling area, a similar situation to that present in the Portuguese coast might be expected. The analysis of 6 paired marine/terrestrial samples, collected during an archaeological excavation in an Iron Age settlement in the margin of the Ría of Arousa, allowed determination of $\Delta R$ values close to zero, although most of them are negative values (Rubinos Pérez et al. 1999). These values, at first sight, seemed to imply a different hydrographic situation (with a nonexistent coastal upwelling) compared with the situation prevailing in the western Portuguese coast during the same period of time. Our research tried to continue the study carried out by our Spanish colleagues in order to identify eventual differences in the marine reservoir effect between the Rías Baixas and the Rías Altas regions or between the western Galician coast and the western Portuguese coast. Nevertheless, the sampling area until now has covered a lesser temporal and spatial extension than that undertaken along the Portuguese coast, and for that reason this study must be considered preliminary.

\section{SAMPLING}

Pairs of closely associated archaeological samples (marine shells/charred wood or bones) from each depositional context were collected from 2 Galician archaeological sites: Peneda del Viso (Pontevedra) and Torre de Hércules (La Coruña). It is assumed that the deposition of both types of samples was simultaneous, or, in other words, that the time of death of the organisms from both reservoirs was the same.

Peneda del Viso, located about $2 \mathrm{~km}$ east of the inner part (the San Simón inlet) of the Ría of Vigo, one of the Rías Baixas, is an Iron Age settlement that was excavated in the early 1990s. Two paired marine/terrestrial samples were collected for dating. Torre de Hércules is a Roman lighthouse from the ancient town of Brigantium, located between Orzán cove and the mouth of the Ría of La Coruña (Hutter and Hauschild 1991). In Medieval times, the lighthouse was transformed into a fortress, the remains of which were discovered during archaeological excavation in 1992/3 in the platform that encloses the tower (Bello Diéguez 2004). The majority of the stratigraphy corresponding to the Medieval occupation is made up of undisturbed thin, dark layers. Their origin is kitchen refuse, including both marine and terrestrial material, which was gathered at the same time and is almost certainly contemporaneous. It is from some of those layers that the analyzed samples were collected.

We tried to eliminate problematical associations through close consultation with the excavators of each sampled site. In order to obtain accurate results, we selected samples in close stratigraphic proximity. In some cases, we measured more than 1 shell species from the same archaeological context. Using different shell species, we tried to test not only if their respective ${ }^{14} \mathrm{C}$ dating results were influenced by dietary or habitat preferences of the analyzed mollusks, but also to identify eventual outliers. For charcoal samples, it was not possible to undertake any prior anthracological analyses in order to overcome the problem of the "old-wood" effect (Kennett et al. 1997; Ascough et al. 2005), which can lead to low or negative $\Delta R$ values. Nevertheless, using more than 10 paired samples from thin archaeological layers in vertical stratigraphic/chronological order, as was the case for Torre de Hércules, any outlier or any charcoal sample suffering from the old-wood effect can be easily identified.

Although the application of an ideal sample protocol (Ascough et al. 2005) was not entirely fulfilled, the methodology used was thought to be the most promising to obtain accurate values for $\Delta \mathrm{R}$. A detailed discussion of these matters, including a more complete description of the sampled archae- 
ological sites as well as all the data obtained from our research, can be found in Soares (2005). Sampling locations are shown in Figure 1.

\section{ANALYTICAL PROCEDURES}

Samples were first cleaned by hand to remove foreign material. Charred wood samples were further decontaminated by acid/alkali/acid digestion. For bone samples, gelatin was extracted using the Longin method (Longin 1970). Marine shell samples were usually restricted to whole valves of the same species with no visual evidence of surface deterioration. Nevertheless, the outermost $30 \%$ by weight, at least, of the shells was discarded by controlled acid leaching $\left(0.5 \mathrm{M} \mathrm{HCl}\right.$ at $\left.25^{\circ} \mathrm{C}\right)$. For some samples, where size allowed, controlled acid hydrolysis was used to separate similarly sized volumes of $\mathrm{CO}_{2}$ representative of the intermediate fraction and the inner fraction of the shells' carbonate structure.

We measured the ${ }^{14} \mathrm{C}$ content by means of the liquid scintillation technique described elsewhere (Soares 1989). Stable isotope enrichment values $\left(\delta^{13} \mathrm{C}\right)$ were determined for the $\mathrm{CO}_{2}$ gas produced at the initial stage of benzene synthesis. ${ }^{14} \mathrm{C}$ ages or the radiometric enrichment $\mathrm{D}^{14} \mathrm{C}$ were calculated in accordance with the definitions recommended by Stuiver and Polach (1977).

\section{RESULTS AND DISCUSSION}

Measurements of the ${ }^{14} \mathrm{C}$ contents of the terrestrial/marine pairs and the resulting $\Delta \mathrm{R}$ values are listed in Table 1. Following Stuiver and Braziunas (1993: Figure 15), $\Delta \mathrm{R}$ values were calculated by converting the terrestrial biosphere sample ${ }^{14} \mathrm{C}$ age from each archaeological context into a marine model age; this marine model age was then deducted from the ${ }^{14} \mathrm{C}$ age of the associated marine shell sample to yield $\Delta \mathrm{R}$.

As already mentioned, in some cases we dated more than 1 sample of the same origin from the same stratigraphic level. A weighted mean was then calculated using $\mathrm{D}^{14} \mathrm{C}$ values. In addition, only the value of $\mathrm{D}^{14} \mathrm{C}$ determined for the inner fraction of marine shell samples (when 2 fractions were obtained and analyzed) is taken into consideration for $\Delta R$ calculation. The $D^{14} C$ value for the intermediate fraction is merely an index of reliability for the inner fraction $\mathrm{D}^{14} \mathrm{C}$ as are the inner and the intermediate fraction $\delta^{13} \mathrm{C}$ values. For uncontaminated marine samples, $\delta^{13} \mathrm{C}$ must be higher than $-3 \%$ (Keith and Anderson 1963).

It must be noted that 2 values, Sac-1858 and Sac-1868, are outliers since their ${ }^{14} \mathrm{C}$ contents are equivalent to those of the respective terrestrial samples taking into account the uncertainties. Also, Sac-1870 shall be an outlier assuming that the value of $R(t)$ calculated with it, $1840 \pm 8{ }^{14} \mathrm{C}$ yr, is not acceptable. Nevertheless, only 3 outliers in 42 results and terrestrial sample ages in accordance with their stratigraphic positions suggest that reliable dates were obtained and the old-wood problem was not important for our charred wood ${ }^{14} \mathrm{C}$ dates nor, consequently, for the $\Delta \mathrm{R}$ values.

In Table 2, the $\Delta \mathrm{R}$ values determined for the Iron Age settlement of O Achadizo (Ría of Arousa) by Rubinos Pérez et al. (1999) are presented. The data shown in Tables 1 and 2 can be divided into 2 sets: one from Iron Age archaeological contexts located near the Rías Baixas and another from Medieval contexts of a site located in the northwestern Galician coast at the mouth of the Ría of La Coruña, one of the Rías Altas. In Table 3, the $\Delta \mathrm{R}$ values are presented for each archaeological context listed in decreasing chronological order. The context age was determined by using samples of terrestrial biosphere origin. These ages are presented as conventional ${ }^{14} \mathrm{C}$ dates and also as calendar dates using the program CALIB rev 5.0.1 (Stuiver and Reimer 1993) and the IntCal04 calibration curve (Reimer et al. 2004). 


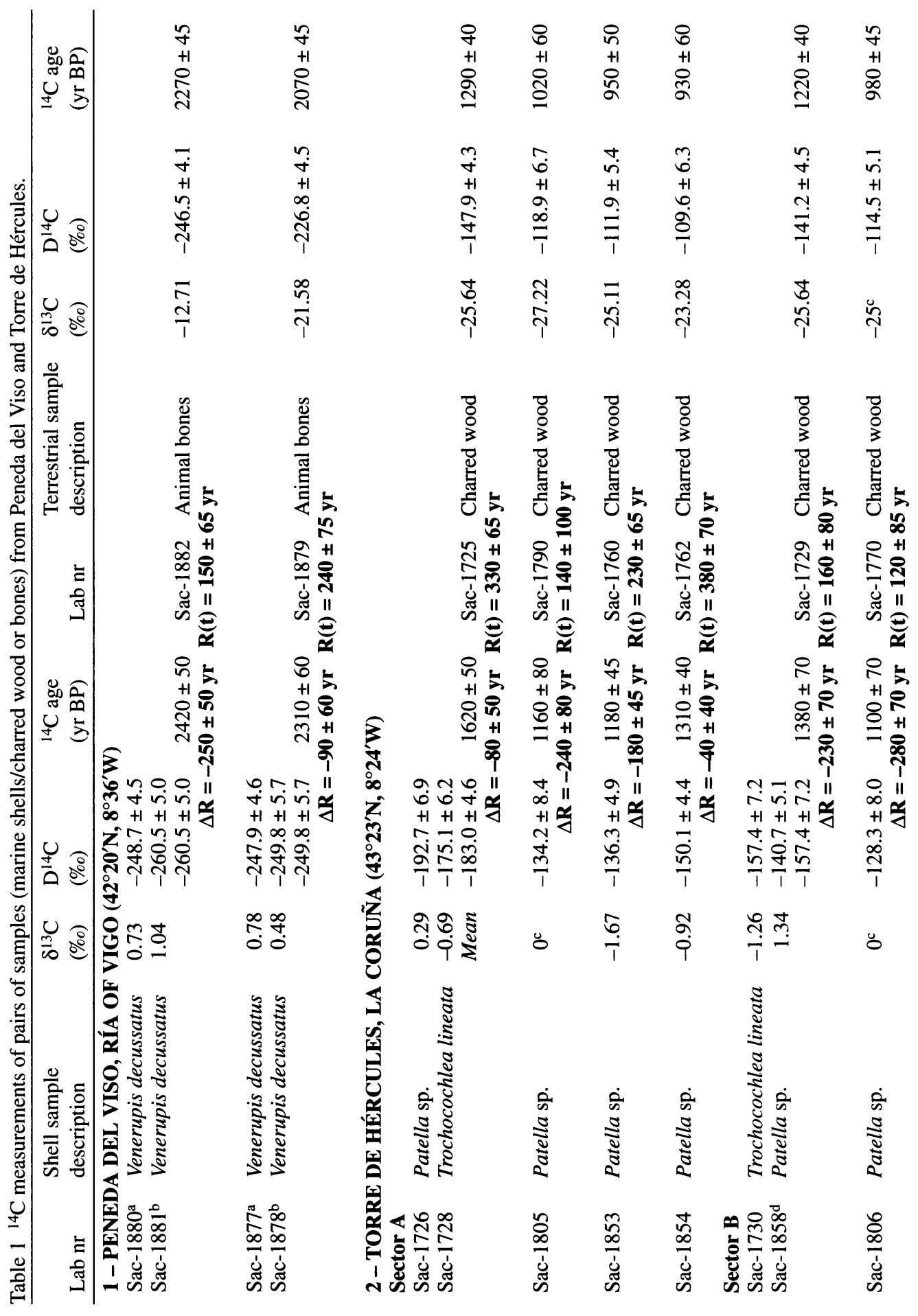




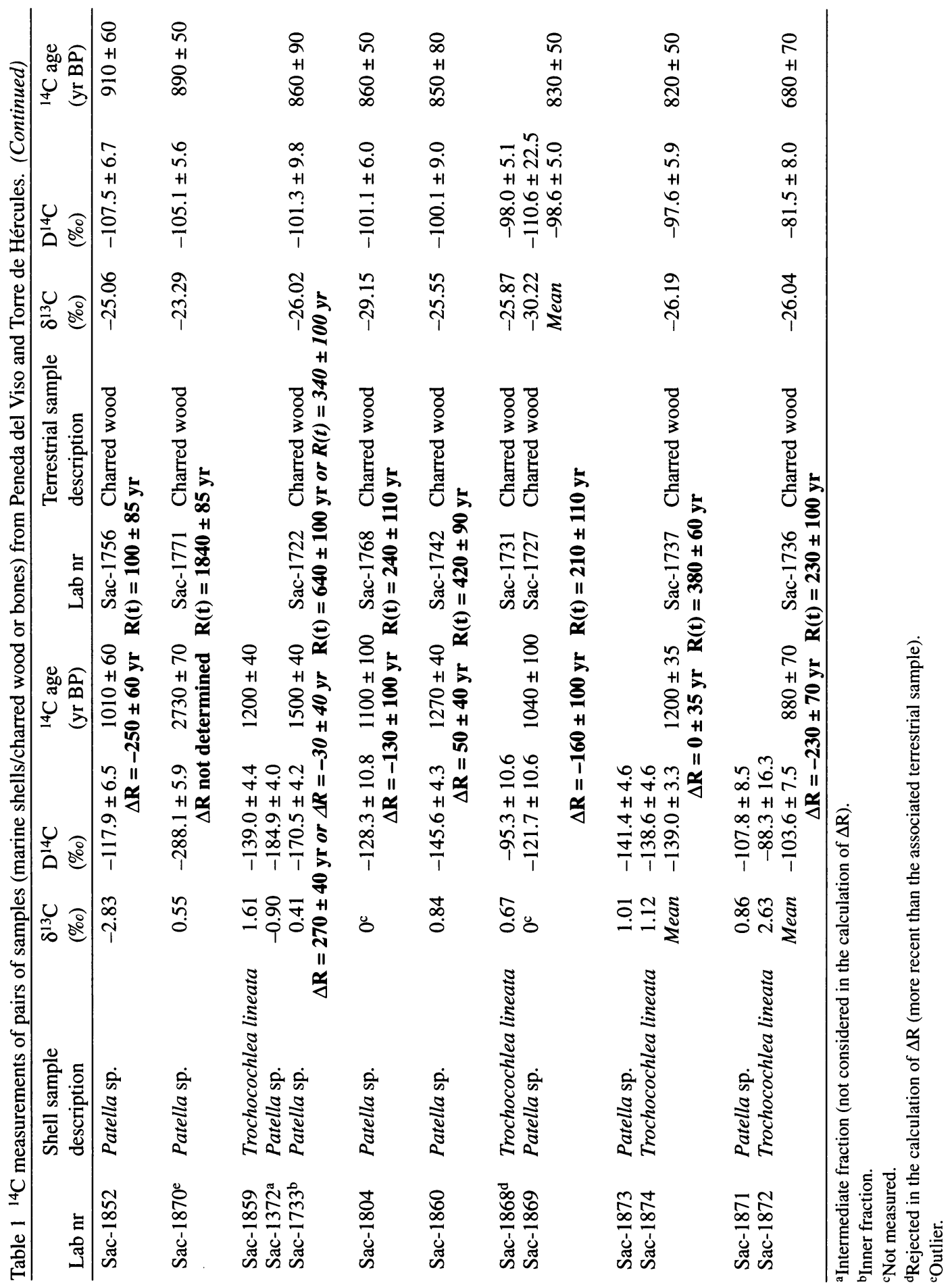


Table $2{ }^{14} \mathrm{C}$ measurements of pairs of samples (marine shells/charred wood or bones) from O Achadizo, Ría of Arousa, following Rubinos Pérez et al. (1999).

\begin{tabular}{|c|c|c|c|c|}
\hline Lab nr & Sample description & $\begin{array}{l}{ }^{14} \mathrm{C} \text { age } \\
\text { (yr BP) }\end{array}$ & $\begin{array}{l}\Delta R \\
\left({ }^{14} \mathrm{C} y r\right)\end{array}$ & $\begin{array}{l}\mathrm{R}(\mathrm{t}) \\
\left({ }^{14} \mathrm{C} \text { yr }\right)\end{array}$ \\
\hline $\begin{array}{l}\text { UtC-5660 } \\
\text { CSIC-1191 }\end{array}$ & $\begin{array}{l}\text { Charred wood } \\
\text { Patella sp. }\end{array}$ & $\begin{array}{l}2440 \pm 29 \\
2716 \pm 27\end{array}$ & $-26 \pm 27$ & $276 \pm 40$ \\
\hline $\begin{array}{l}\text { CSIC-1212 } \\
\text { CSIC-1192 } \\
\text { CSIC-1193 } \\
\end{array}$ & $\begin{array}{l}\text { Charred wood } \\
\text { Patella sp. } \\
\text { Trochocochlea lineata }\end{array}$ & $\begin{array}{l}2441 \pm 44 \\
2789 \pm 28 \\
2963 \pm 28 \\
\end{array}$ & $\begin{array}{l}46 \pm 28 \\
\text { or } \\
220 \pm 28^{a}\end{array}$ & $\begin{array}{l}348 \pm 52 \\
\text { or } \\
522 \pm 52^{\mathrm{a}}\end{array}$ \\
\hline $\begin{array}{l}\text { CSIC-1312 } \\
\text { CSIC- } 1194 \\
\end{array}$ & $\begin{array}{l}\text { Animal bones } \\
\text { Patella sp. }\end{array}$ & $\begin{array}{l}2390 \pm 32 \\
2706 \pm 27 \\
\end{array}$ & $-4 \pm 27$ & $316 \pm 42$ \\
\hline $\begin{array}{l}\text { CSIC- } 1310 \\
\text { CSIC- } 1195 \\
\end{array}$ & $\begin{array}{l}\text { Charred wood } \\
\text { Patella sp. }\end{array}$ & $\begin{array}{l}2361 \pm 30 \\
2686 \pm 28 \\
\end{array}$ & $-14 \pm 28$ & $325 \pm 41$ \\
\hline $\begin{array}{l}\text { CSIC-1211 } \\
\text { CSIC-1198 } \\
\end{array}$ & $\begin{array}{l}\text { Animal bones } \\
\text { Patella sp. }\end{array}$ & $\begin{array}{l}2252 \pm 42 \\
2401 \pm 26 \\
\end{array}$ & $-183 \pm 26$ & $149 \pm 49$ \\
\hline $\begin{array}{l}\text { CSIC-1314 } \\
\text { CSIC-1196 }\end{array}$ & $\begin{array}{l}\text { Animal bones } \\
\text { Patella sp. }\end{array}$ & $\begin{array}{l}2214 \pm 32 \\
2544 \pm 26\end{array}$ & $-23 \pm 26$ & $330 \pm 41$ \\
\hline
\end{tabular}

${ }^{\mathrm{a}}$ Less reliable value (see text).

Table 3 Reservoir effect values for the Galician coast.

\begin{tabular}{|c|c|c|c|c|c|}
\hline Archaeological site & $\begin{array}{l}{ }^{14} \mathrm{C} \text { age } \\
\text { (BP) }\end{array}$ & $\begin{array}{l}\text { cal BC/cal AD } \\
(2 \sigma)\end{array}$ & $\begin{array}{l}\text { cal BPa } \\
(2 \sigma)\end{array}$ & $\begin{array}{l}\Delta \mathrm{R} \\
\left({ }^{14} \mathrm{C} \mathrm{yr}\right)\end{array}$ & $\begin{array}{l}\mathrm{R}(\mathrm{t}) \\
\left({ }^{14} \mathrm{C} \mathrm{yr}\right)\end{array}$ \\
\hline \multicolumn{6}{|c|}{ Iron Age archaeological contexts (Rías Baixas) } \\
\hline O Achadizo ${ }^{b}$ & $2440 \pm 29$ & cal BC $750-410$ & $2360-2700$ & $-26 \pm 27$ & $276 \pm 40$ \\
\hline O Achadizo ${ }^{\mathrm{b}}$ & $2441 \pm 44$ & cal BC $760-400$ & $2350-2700$ & $\begin{array}{c}46 \pm 28 \\
220 \pm 28^{c}\end{array}$ & $\begin{array}{l}348 \pm 52 \\
522 \pm 52^{c}\end{array}$ \\
\hline O Achadizo ${ }^{b}$ & $2390 \pm 32$ & cal BC 730-390 & $2340-2680$ & $-4 \pm 27$ & $316 \pm 42$ \\
\hline O Achadizo A $^{\mathrm{b}}$ & $2361 \pm 30$ & cal BC 520-380 & $2330-2470$ & $-14 \pm 28$ & $325 \pm 41$ \\
\hline Peneda del Viso & $2270 \pm 45$ & $\mathrm{cal}$ BC $400-200$ & $2150-2350$ & $-250 \pm 50$ & $150 \pm 65$ \\
\hline O Achadizo ${ }^{b}$ & $2252 \pm 42$ & cal BC $400-200$ & $2150-2350$ & $-183 \pm 26$ & $149 \pm 49$ \\
\hline O Achadizo ${ }^{b}$ & $2214 \pm 32$ & cal BC $380-200$ & $2150-2330$ & $-23 \pm 26$ & $330 \pm 41$ \\
\hline Peneda del Viso & $2070 \pm 45$ & cal BC 200-cal AD 40 & $1900-2150$ & $-90 \pm 60$ & $240 \pm 75$ \\
\hline \multicolumn{6}{|c|}{ Medieval archaeological contexts (Rías Altas) } \\
\hline Torre de Hércules & $1290 \pm 40$ & cal AD 650-860 & $1090-1300$ & $-80 \pm 50$ & $330 \pm 65$ \\
\hline Torre de Hércules & $1220 \pm 40$ & cal AD 680-890 & $1060-1270$ & $-230 \pm 70$ & $160 \pm 80$ \\
\hline Torre de Hércules & $1020 \pm 60$ & cal AD 890-1160 & 790-1060 & $-240 \pm 80$ & $140 \pm 100$ \\
\hline Torre de Hércules & $980 \pm 45$ & cal AD 980-1160 & 790-970 & $-280 \pm 70$ & $120 \pm 85$ \\
\hline Torre de Hércules & $950 \pm 50$ & cal AD 1000-1210 & $740-950$ & $-180 \pm 45$ & $230 \pm 65$ \\
\hline Torre de Hércules & $930 \pm 60$ & cal AD $1000-1220$ & $730-950$ & $-40 \pm 40$ & $380 \pm 70$ \\
\hline Torre de Hércules & $910 \pm 60$ & cal AD 1020-1250 & $700-930$ & $-250 \pm 60$ & $100 \pm 85$ \\
\hline Torre de Hércules & $860 \pm 90$ & cal AD 1020-1290 & $660-930$ & $\begin{array}{l}270 \pm 40 \\
-30 \pm 40^{c}\end{array}$ & $\begin{array}{l}640 \pm 100 \\
340 \pm 100^{c}\end{array}$ \\
\hline Torre de Hércules & $860 \pm 50$ & cal AD 1040-1260 & $690-910$ & $-130 \pm 100$ & $240 \pm 110$ \\
\hline Torre de Hércules & $850 \pm 80$ & cal AD 1030-1280 & $670-920$ & $50 \pm 40$ & $420 \pm 90$ \\
\hline Torre de Hércules & $830 \pm 50$ & cal AD 1050-1280 & $670-900$ & $-160 \pm 100$ & $210 \pm 110$ \\
\hline Torre de Hércules & $820 \pm 50$ & cal AD $1050-1280$ & $670-900$ & $0 \pm 35$ & $380 \pm 60$ \\
\hline Torre de Hércules & $680 \pm 70$ & cal AD 1220-1410 & $540-730$ & $-230 \pm 70$ & $200 \pm 100$ \\
\hline
\end{tabular}


As can be seen in the tables, the $\Delta \mathrm{R}$ values determined from Iron Age contexts are all negative values, with the exception of those calculated for the context dated to $2441 \pm 44 \mathrm{BP}(760-400 \mathrm{cal} \mathrm{BC}$ at $2 \sigma$ ). Two positive values were determined depending upon which shell sample was used for the calculation (see Table 2). Nevertheless, studies using other paleoenvironmental proxies point out that between $975 \mathrm{cal} \mathrm{BC}$ and cal AD 1000, the Rías Baixas were not influenced by coastal upwelling (Diz et al. 2002; Álvarez et al. 2005; González-Álvarez et al. 2005). A $\Delta \mathrm{R}$ value of $220 \pm 28{ }^{14} \mathrm{C}$ yr would be in accordance with an intense upwelling, but it seems that it would have not occurred at $760-400 \mathrm{cal} \mathrm{BC}$. Thus, that value must be considered less reliable. On the contrary, the $\Delta \mathrm{R}$ value of $46 \pm 28{ }^{14} \mathrm{C}$ yr seems to be more acceptable. The Iron Age $\Delta \mathrm{R}$ values are, in turn, in accordance with the studies referred to above, e.g. these values reflect restricted environments (relative isolation and dominance of the estuarine condition in the rías hydrography), where strong stratification of the water column leads to a greater equilibrium with the contemporary atmosphere.

A set of $13 \Delta \mathrm{R}$ values was determined from the Medieval contexts of Torre de Hércules (see Table 3 and Figure 2). We can also divide this set into 2 subsets: one with the first 7 values, which also indicate, besides a high variability, a consistent, strongly reduced offset between atmospheric and surface ocean ${ }^{14} \mathrm{C}$ specific activity during the period cal AD 800-1200 at $2 \sigma(1200-800 \mathrm{cal} \mathrm{BP})$; and another subset with the remaining 6 values where the $\Delta R$ has a high variability, too, but where some positive values occur. It must be noted that at $860 \pm 90 \mathrm{BP}, 2$ values of $\Delta \mathrm{R}$ were calculated due, as it also happened with a paired sample from $\mathrm{O}$ Achadizo, to the great difference between the ages determined for the 2 shell samples associated with the terrestrial biosphere sample. The Patella sample was subdivided into the intermediate and the inner fraction with statistically similar ${ }^{14} \mathrm{C}$ dates of $870 \pm 90 \mathrm{BP}$ for the western Portuguese coast; we also obtained a peak $\left(620 \pm 70{ }^{14} \mathrm{C} \mathrm{yr}\right)$ for $\Delta \mathrm{R}$ (Soares and Dias 2006). We think that the value of $270 \pm 40{ }^{14} \mathrm{C}$ yr for $\Delta \mathrm{R}$ determined at $860 \pm 90$ BP for the Galician coast is more reliable than that of $-30 \pm 40{ }^{14} \mathrm{C}$ yr determined with the Throchocochlea sample.

This peak found in the 2 data sets (see Figure 2) matches the one found at $\sim 800 \mathrm{cal}$ BP by deMenocal et al. (2000) in a core taken off Cape Blanc, Mauritania $\left(20^{\circ} 45^{\prime} \mathrm{N}, 18^{\circ} 35^{\prime} \mathrm{W}\right)$. Following these researchers, the event of $0.80 \mathrm{cal} \mathrm{kyr} \mathrm{BP}$, associated to another at $0.35 \mathrm{cal} \mathrm{kyr} \mathrm{BP}$, and those at 10.2, 8.0, 6.0, 4.6, 3.0, and $1.9 \mathrm{cal} \mathrm{kyr} \mathrm{BP}$, represent a succession of Holocene cooling events recurring about every $1500 \pm 500 \mathrm{yr}$ (see also Bond et al. 1997, 2001; McDermott et al. 2001). These data within the respective dating uncertainties document that the subpolar, temperate, and subtropical North Atlantic experienced a comparable and roughly synchronous succession of cooling events (the so-called Bond events) and climate instabilities. These events are associated with "abrupt" climatic changes. For instance, the 0.80-kyr event occurred between the Medieval Warm Period and the Little Ice Age.

All these data determined by us agree with other paleoceanographic and paleoenvironmental proxies for the western and northwestern Galician coast. Following Álvarez et al. (2005), a combined study of biomarkers and coccolith assemblages in a core from the Ría of Vigo indicates that during the last $3000 \mathrm{yr}, 3$ intervals with different paleoenvironmental conditions can be found. The first, between $975 \mathrm{BC}$ and $\mathrm{AD} 252$, corresponds to a transition from a warmer to a cooler period. The second interval (AD 252-1368) represents a humid period with a strong fluvial input into the ría. The third interval (AD 1368-1950) represents, in turn, a well-developed upwelling system and, consequently, a strong ría-ocean connection. González-Álvarez et al. (2005), using the data obtained from a gravity core retrieved from the western Galician shelf, concluded that at $\sim 2850$ cal BP, coinciding with the Subboreal/Subatlantic transition, a storm regime existed and at AD 1420 an intense upwelling pulse occurred. Diz et al. (2002) have reconstructed the hydrographic evolution of the Ría of Vigo during 


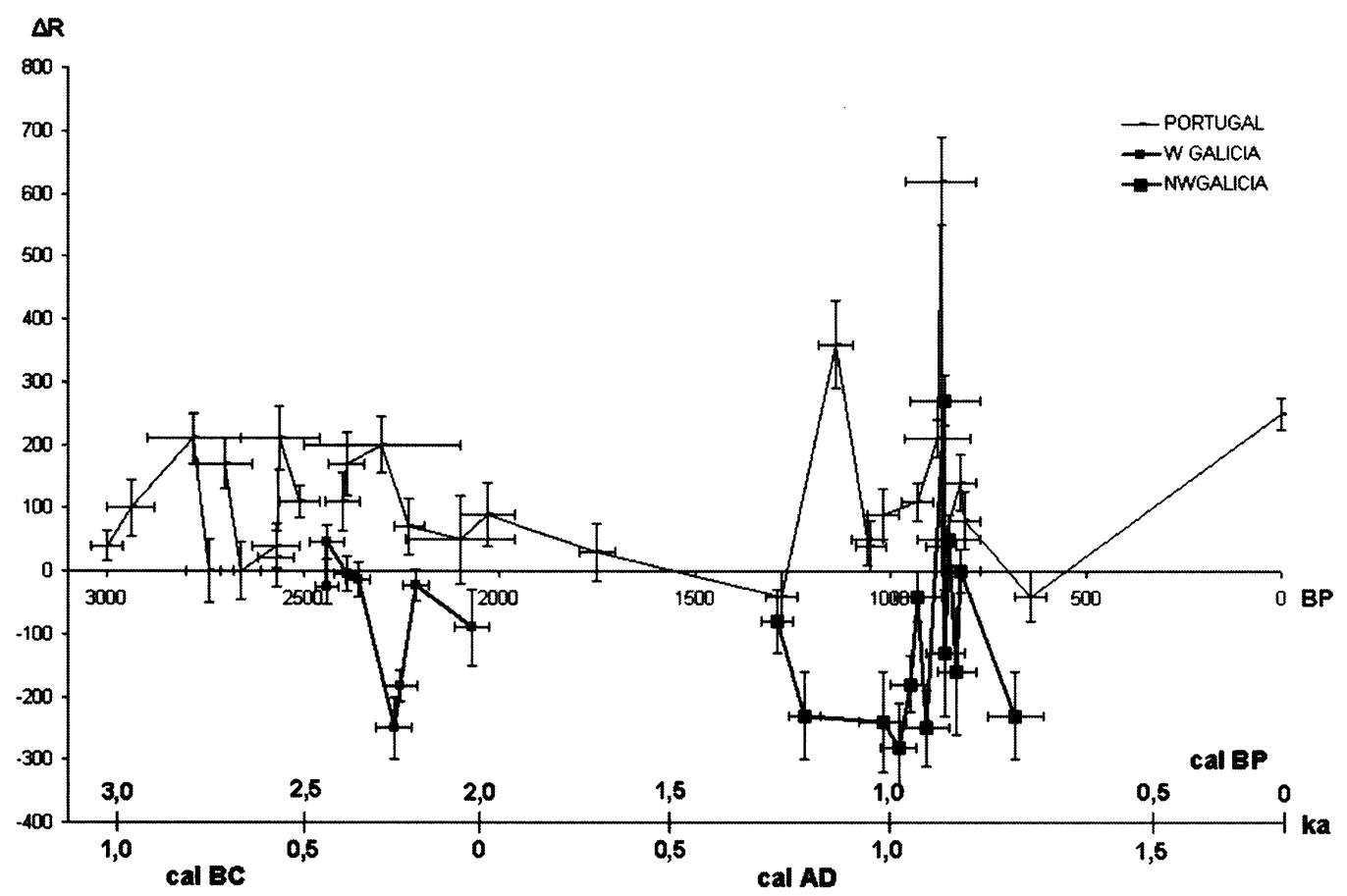

Figure 2 The variability in ocean reservoir effect off the Galician coast during the last $3 \mathrm{kyr}$ compared with the variability for the western Portuguese coast. $\Delta \mathrm{R}( \pm 1 \sigma)$ values are plotted versus terrestrial ${ }^{14} \mathrm{C}$ ages $( \pm 1 \sigma)$.

the last $3000 \mathrm{yr}$ : from $975 \mathrm{cal} \mathrm{BC}$ to cal AD 1000 the hydrographic situation corresponded to a restricted environment where the exchange with the open ocean is small, but at cal AD 1000 an intensification of coastal upwelling is recorded that continues until the present.

If we compare these results from the Galician coast with those obtained from the Portuguese coast for the same periods of time, as is done in Figure 2, an interesting feature can be identified, i.e. the $\Delta \mathrm{R}$ values from Galicia are invariably lower than those from Portugal. This difference is explained by the existence during the Iron Age and the Medieval period of a coastal upwelling of some intensity off the Portuguese coast (mean $\Delta R=95 \pm 15{ }^{14} \mathrm{C}$ yr, see Soares and Dias 2006:59), while the Galician coast was characterized until $860 \pm 90 \mathrm{BP}$ by a weak or nonexistent coastal upwelling. This fact implies restricted environments inside the rías, i.e. strong stratification of the water column that led to a greater equilibrium with the contemporary atmosphere and, consequently, to an enrichment in ${ }^{14} \mathrm{C}$ of the surface waters.

\section{CONCLUSION}

Reservoir ages can provide information concerning the intensity of coastal upwelling and paleoenvironmental processes in marine regions influenced by this phenomenon. A record of past reservoir ages is preserved in the ${ }^{14} \mathrm{C}$ content of contemporary marine and terrestrial material.

The $\Delta \mathrm{R}$ results from the western and northwestern Galician coasts (Rías Baixas and Rías Altas regions, respectively) for the period 2500 to $\sim 900 \mathrm{BP}$ point to a reduced offset between atmospheric and surface water ${ }^{14} \mathrm{C}$ content, suggesting the existence of a restricted environment in the Galician Rías and a small exchange with the open ocean. This fact, due to a weak or nonexistent coastal 
upwelling, leads to a strong stratification of the water column and, consequently, to a greater equilibrium with the contemporary atmosphere.

At $860 \pm 90 \mathrm{BP}(660-930 \mathrm{cal} \mathrm{BP}$ at $2 \sigma)$, a peak in the $\Delta \mathrm{R}$ series was obtained, which is coincident with another obtained at $870 \pm 90 \mathrm{BP}$ for the western Portuguese coast and matches that found at $\sim 800$ cal BP by deMenocal et al. (2000) in a core taken off NW Africa. After that date, the $\Delta \mathrm{R}$ values and other proxies suggest the occurrence of an active upwelling off the western and northwestern Galician coast that increased in intensity until modern levels were reached.

\section{ACKNOWLEDGMENTS}

We wish to express our gratitude to José Bello Diéguez and Carlos Rodríguez López for the samples and fruitful discussions about the archaeological stratigraphy from where the samples were collected.

\section{REFERENCES}

Álvarez MC, Flores JA, Sierro FJ, Diz P, Francés G, Pelejero C, Grimalt J. 2005. Millennial surface water dynamics in the Ría de Vigo during the last 3000 years as revealed by coccoliths and molecular biomarkers. Palaeogeography, Palaeoclimatology, Palaeoecology 218(1):1-13.

Álvarez-Salgado XA, Rosón G, Pérez FF, Pazos Y. 1993. Hydrographic variability off the Rías Baixas (NW Spain) during the upwelling season. Journal of Geophysical Research 98(C8):14,447-56.

Álvarez-Salgado XA, Gago J, Míguez BM, Gilcoto M, Pérez FF. 2000. Surface waters of the NW Iberian Margin: upwelling on the shelf versus outwelling of upwelled waters from the Rías Baixas. Estuarine, Coastal and Shelf Science 51(6):821-37.

Ascough PL, Cook GT, Dugmore AJ, Barber J, Higney E, Scott EM. 2004. Holocene variations in the Scottish marine radiocarbon reservoir effect. Radiocarbon 46(2):611-20.

Ascough P, Cook G, Dugmore A. 2005. Methodological approaches to determining the marine radiocarbon reservoir effect. Progress in Physical Geography 29(4):532-47.

Bello Diéguez JM. 2004. Excavaciones bajo el Faro Romano de la Torre de Hércules. URL: http:// www.ctv.es/USERS/sananton/torre.pdf. In Spanish.

Bond G, Showers W, Cheseby M, Lotti R, Almasi P, deMenocal P, Priore P, Cullen H, Hadjas I, Bonani G. 1997. A pervasive millennial-scale cycle in North Atlantic Holocene and glacial climates. Science 278(5341):1257-66.

Bond G, Kromer B, Beer J, Muscheler R, Evans MN, Showers W, Hoffmann S, Lotti-Bond R, Hajdas I, Bonani G. 2001. Persistent solar influence on North Atlantic climate during the Holocene. Science 294(5549):2130-6.

Borges AV, Frankignoulle M. 2002. Aspects of dissolved inorganic carbon dynamics in the upwelling system off the Galician coast. Journal of Marine Systems
32(1-3):181-98.

Castro CG, Pérez FF, Álvarez-Salgado XA, Fraga F. 2000. Coupling between the thermohaline, chemical and biological fields during two contrasting upwelling events off the NW Iberian Peninsula. Continental Shelf Research 20(2):189-210.

deMenocal P, Ortiz J, Guilderson T, Sarnthein M. 2000. Coherent high- and low-latitude climate variability during the Holocene Warm Period. Science 288(5474):2198-202.

Diffenbaugh NS, Sloan LC, Snyder MA. 2003. Orbital suppression of wind-driven upwelling in the California Current at 6 ka. Paleoceanography 18(2):1051; doi: 10.1029/2002PA000865.

Diz P, Francés G, Pelejero C, Grimalt JO, Vilas F. 2002. The last 3000 years in the Ría de Vigo (NW Iberian Margin): climatic and hydrographic signals. The $\mathrm{Ho}$ locene 12(4):459-68.

Ferreira DB. 1984. Le systeme climatique de l'Upwelling Ouest Iberique [Report \#19 of the Linha de Acção de Geografia Física]. Lisbon: Centro de Estudos Geográficos. INIC. 92 p. In French.

Fiúza AFG. 1982. The Portuguese coastal upwelling system. In: Actual Problems of Oceanography in Portugal. Lisbon: Junta Nacional de Investigação Científica e Tecnológica. p 45-71.

Fiúza AFG. 1983. Upwelling patterns off Portugal. In: Suess E, Thiede J, editors. Coastal Upwelling. Its Sediment Record. New York: Plenum. p 85-98.

Fiúza AFG, Macedo ME, Guerreiro MR. 1982. Climatological space and time variation of the Portuguese coastal upwelling. Oceanologica Acta 5(1):31-40.

González-Álvarez R, Bernárdez P, Pena LD, Francés G, Prego R, Diz P, Vilas F. 2005. Paleoclimatic evolution of the Galician continental shelf (NW of Spain) during the last 3000 years: from a storm regime to present conditions. Journal of Marine Systems 54(1-4):24560.

Hutter S, Hauschild T. 1991. El Faro Romano de la 
Coruña. A Coruña: Ediciós do Castro. 99 p. In Spanish.

Ingram BL. 1998. Differences in radiocarbon age between shell and charcoal from a Holocene shellmound in northern California. Quaternary Research 49(1): 102-10.

Keith ML, Anderson GM. 1963. Radiocarbon dating: fictitious results with mollusk shells. Science 141(3581): 634-7.

Kennett DJ, Ingram BL, Erlandson JM, Walker P. 1997. Evidence for temporal fluctuations in marine radiocarbon reservoir ages in the Santa Barbara Channel, southern California. Journal of Archaeological Science 24(11): 1051-9.

Longin R. 1970. Extraction du collagene des os fossils pour leur datation par la methode du carbone-14 $[\mathrm{PhD}$ dissertation]. Lyon: Faculté des Sciences de l'Université de Lyon. 70 p. In French.

Lorenzo LM, Arbones B, Tilstone GH, Figueras FG. 2005. Across-shelf variability of phytoplankton composition, photosynthetic parameters and primary production in the NW Iberian upwelling system. Journal of Marine Systems 54(1-4):157-73.

McDermott F, Mattey DP, Hawkesworth C. 2001. Centennial-scale Holocene climate variability revealed by a high-resolution speleothem $\delta^{18} \mathrm{O}$ record from SW Ireland. Science 294(5545):1328-31.

Nogueira E, González-Nuevo G, Morán XAG, Varela M, Bode A. 2003. Hydrological structures along the $N$ and NW Iberian shelf during the winter-spring transition. Thalassas 19(2b):65-7.

Prego R, Bao R. 1997. Upwelling influence on the Galician coast: silicate in shelf water and underlying surface sediments. Continental Shelf Research 17(3): 307-18.

Prego R, Barciela MC, Varela M. 1999. Nutrient dynamics in the Galician coastal area (northwestern Iberian Peninsula): Do the Rías Bajas receive more nutrient salts than the Rías Altas? Continental Shelf Research 19(3):317-34.

Reimer PJ, Baillie MGL, Bard E, Bayliss A, Beck JW, Bertrand CJH, Blackwell PG, Buck CE, Burr GS, Cutler KB, Damon PE, Edwards RL, Fairbanks RG, Friedrich M, Guilderson TP, Hogg AG, Hughen KA, Kromer B, McCormac G, Manning S, Bronk Ramsey C, Reimer RW, Remmele S, Southon JR, Stuiver M, Talamo S, Taylor FW, van der Plicht J, Weyhenmeyer CE. 2005. IntCal04 terrestrial radiocarbon age calibration, 0-26 cal kyr BP. Radiocarbon 46(3):1029-58.

Rubinos Pérez A, Fábregas Valcarce R, Alonso Mathias F, Concheiro Coello A. 1999. Las fechas C-14 del Castro de O Achadizo (Boiro, A Coruña): problemática de la calibración de conchas marinas. Traba- jos de Prehistoria 56(1):147-55. In Spanish.

Soares AMM. 1989. O Efeito de Reservatório Oceânico nas Águas Costeiras de Portugal Continental. Sacavém: Instituto de Ciências e Engenharia Nucleares (Instituto Nacional de Engenharia e Tecnologia Industrial). 135 p. In Portuguese.

Soares AMM. 1993. The ${ }^{14} \mathrm{C}$ content of marine shells: evidence for variability in coastal upwelling off Portugal during the Holocene. In: Isotope Techniques in the Study of Past and Current Environmental Changes in the Hydrosphere and the Atmosphere. Vienna: International Atomic Energy Agency (IAEA). p 471-85.

Soares AMM. 2005. Variabilidade do "Upwelling" Costeiro durante o Holocénico nas Margens Atlânticas Ocidental e Meridional da Península Ibérica [PhD dissertation]. Faro: Faculdade de Ciências do Mar e do Ambiente, Universidade do Algarve. In Portuguese.

Soares AMM, Cabral JMP. 1993. Idades aparentes das conchas marinhas provenientes da costa portuguesa e a sua variação ao longo do Holocénico. In: El Cuaternario en España y Portugal. Madrid: Associacion Española para el Estudio del Cuaternario/Grupo de Trabalho Português para o Estudo do Quaternário. Volume 2. p 869-80. In Portuguese.

Soares AMM, Dias JMA. 2006. Coastal upwelling and radiocarbon-evidence for temporal fluctuations in ocean reservoir effect off Portugal during the Holocene. Radiocarbon 48(1):45-60.

Stuiver M, Braziunas TF. 1993. Modeling atmospheric ${ }^{14} \mathrm{C}$ influences and ${ }^{14} \mathrm{C}$ ages of marine samples to 10,000 BC. Radiocarbon 35(1):137-89.

Stuiver M, Polach HA. 1977. Discussion: reporting of ${ }^{14} \mathrm{C}$ data. Radiocarbon 19(3):355-63.

Stuiver M, Reimer PJ. 1993. Extended ${ }^{14} \mathrm{C}$ data base and revised CALIB $3.0{ }^{14} \mathrm{C}$ age calibration. Radiocarbon 35(1):215-30.

Stuiver M, Pearson GW, Braziunas T. 1986. Radiocarbon age calibration of marine samples back to $9000 \mathrm{cal} \mathrm{yr}$ BP. Radiocarbon 28(2B):980-1021.

Torres R, Barton ED, Miller P, Fanjul E. 2003. Spatial patterns of wind and sea surface temperature in the Galician upwelling region. Journal of Geophysical Research 108(C4): 3130; doi: 10.1029/ 2002JC001361.

Varela RA, Rosón G, Herrera JL, Torres-López S, Fernández-Romero A. 2005. A general view of the hydrographic and dynamical patterns of the Rías Baixas adjacent sea area. Journal of Marine Systems 54(1-4): 97-113.

Wooster WS, Bakun A, McLain DR. 1976. The seasonal upwelling cycle along the eastern boundary of the North Atlantic. Journal of Marine Research 34:13141. 